\title{
The Implementation of Halal Tourism in Indonesia National Park
}

\author{
Bhayu Rhama \\ Department of Public Administration \\ Universitas Palangka Raya \\ Palangka Raya, Indonesia \\ bhayurhama@fisip.upr.ac.id
}

\author{
Mochamad Doddy Syahirul Alam \\ Department of Government Studies \\ Universitas Palangka Raya \\ Palangka Raya, Indonesia \\ doddyfisip@gmail.com
}

\begin{abstract}
Halal tourism is a new phenomenon based on demographic factors and needs to be taken into consideration by tourism destinations. Nature tourism, especially tourism in national parks, in this case, also has the potential to become a halal tourism destination. However, the parks' halal value still requires special consideration in some areas such as the provision of halal tour packages, worship facilities, visitor status and interaction with local communities. Moreover, considering that recreation is the fundamental activity of tourism that has no boundary, including religion so that the development of halal tourism in national parks still needs aware to the consumers' consumptive behavior.
\end{abstract}

Keywords: halal tourism, national park, tour packages, halal facilities, Muslim tourists

\section{INTRODUCTION}

Demographics is a factor that influences tourism activities. Religious factor, such as Islam, also become one of the demographic elements that attract the attention of the tourism market. This is driven by the rise of tourists from the Middle East who have a pattern of luxury shopping so that the theme of halal tourism emerges by focusing on Muslim tourists [1].

Nevertheless, halal tourism is a new concept and its application needs special attention even for countries that representing Islam behaviors. One of the reason is that it cannot be denied that the tourism activity is generally motivated by the nature of human consumptive behavior controlled by capitalism so that hedonism factor is quite visible in tourism activities[2]- [8]. For example, some tourist areas in Indonesia cannot fully implement the concept of halal tourism because alcohol sales or prostitution are still found even though those are prohibited in Islamic norms [9]. Therefore, some authors end up suggesting that halal tourism is only applicable to religious-based tourism such as pilgrim, which is a visit to sacred destinations [10], such as visits to Mecca, Medina, Kadhimain or Jerusalem [9].

However, the demand to provide tour packages for Muslim tourists to regular tourism destinations is increasing. Though religion (Islam in this case) is a system of norms that cannot be separated from the daily life of the individual, therefore it is possible that religious tourists tend to avoid tourist attractions that are not in accordance with his religious beliefs [1]. This fact encourages tourist destinations to adapt with religious norms in order to attract religious tourists. Therefore, with the rise of the upper middle class, especially from the Middle East countries, the demand for organized halal tourist at regular tourism destinations is emerges dramatically [11].

Indonesia as one of the countries that predominantly Muslim easily becomes a source of Muslim tourists as well as Muslim tourism destinations that have an important role in the world. This is evidenced by the acquisition of 12 awards out of 16 categories obtained by Indonesia in the World Halal Tourism Award 2016 in Abu Dhabi, involving 1.9 million votes from 116 countries [12]. These 12 award categories are spread out from the best for the world's best halal airline (Garuda Indonesia) to the world's best halal cultural destinations (Aceh) (see Table 1.)

Table 1. World Halal Tourism Award 2016

\begin{tabular}{|c|c|c|c|}
\hline No & Category & Winner & Country \\
\hline 1 & $\begin{array}{l}\text { World's Best Airline for Halal } \\
\text { Travellers }\end{array}$ & Garuda Indonesia & Indonesia \\
\hline 2 & $\begin{array}{l}\text { World's Best Airport for Halal } \\
\text { Travellers }\end{array}$ & $\begin{array}{lrr}\text { Sultan } & \text { Iskandar } & \text { Muda } \\
\text { International Airport } & \\
\end{array}$ & Indonesia \\
\hline 3 & World's Best Family Friendly Hotel & The Rhadana, Kuta, Bali & Indonesia \\
\hline 4 & $\begin{array}{l}\text { World's Most Luxurious Family } \\
\text { Friendly Hotel }\end{array}$ & The Trans Luxury Hotel, Bandung & Indonesia \\
\hline 5 & World's Best Halal Apartment Hotel & PNB Perdana Hotel and Suites & Malaysia \\
\hline 6 & World's Best Halal Beach Resort & Novotel Lombok Resort and Villas & Indonesia \\
\hline 7 & World's Best Halal Tour Operator & ERO Tour, West Sumatera & Indonesia \\
\hline 8 & World's Best Halal Travel Website & $\begin{array}{l}\text { www.wonderfullomboksumbawa. } \\
\text { com }\end{array}$ & Indonesia \\
\hline 9 & World's Best Halal Cruise Company & Halalcruise.org & Turki \\
\hline 10 & $\begin{array}{l}\text { World's Best Halal Honeymoon } \\
\text { Destination }\end{array}$ & $\begin{array}{l}\text { Sembalun Valley Region, West } \\
\text { Nusa Tenggara }\end{array}$ & Indonesia \\
\hline 11 & $\begin{array}{l}\text { World's Best Hajj and Umrah } \\
\text { Operator }\end{array}$ & ESQ Tours and Travel & Indonesia \\
\hline 12 & World's Best Haij and Umrah Hotel & Tabung Haji & Malaysia \\
\hline 13 & World's Best Halal Destination & West Sumatera & Indonesia \\
\hline 14 & $\begin{array}{l}\text { World's Best Halal Culinary } \\
\text { Destination }\end{array}$ & West Sumatera & Indonesia \\
\hline 15 & $\begin{array}{l}\text { World's Best Halal Cultural } \\
\text { Destination }\end{array}$ & Aceh & Indonesia \\
\hline 16 & $\begin{array}{l}\text { World's Best Non-OIC Emerging } \\
\text { Halal Destination }\end{array}$ & Japan & Japan \\
\hline
\end{tabular}

Source: http://itwabudhabi.com/halal-awards/2016-winners.htm

However, based on Table 1 above, it appears that the World Halal Tourism Award does not have a category of natural tourism, particularly tourism in protected areas such as national parks. Those existent categories are focus mostly on 
tourism providers with a small part of tourist destinations categories that focus on culture, culinary and mass tourism. Therefore, the question arises in how the relevance of nature tourism in protected areas, especially national parks, in the perspective of halal tourism. Is tourism in a national park can be a part of halal tourism? Moreover, how to develop tourism in a national park based on halal tourism perspective?

In contrast to mass tourism that is rapidly developing and revolutionary, the nature tourism in protected areas (national parks) develops slowly although its visitors tend to increase [13]. It is also supported by Carson and Carson [14] study that the attractiveness of landscapes as a major element of tourism in national parks is considered: (i) having low diversification of complementary activities and products, (ii) having shortterm visits, (iii) high visitor turnover and (iv) low repeat visits.

Generally, those lack of tourism elements above exists because (i) the location of the national park is mostly located quite a distance from the city center, has low population density, and emphasis on natural-based attraction such as green space, waterscape and contemplation site [15]. (ii) tourism activities in national parks are only a secondary mission to self-financing conservation sites (especially national parks in developing countries) and (iii) levelling up public awareness on the importance of natural sustainability for protecting the environment [16] [17].

The national parks' situation discussed above certainly limit the visitors to interact with the environment, including social interaction, which potentially obscures the halal or nonhalal perspective. However, based on tourists' motivation for enjoying the parks in order to find a place of contemplation ${ }^{18-}$ ${ }^{21}$ then tourism in national parks has a chance to be part of the halal tourism destination. Moreover, the perspective of tourism elements owned by the national park is still the same as regular tourism (e.g. accommodation, guide services) so they can be assessed whether it is worth or not to consider as a halal product.

The halal level of a tourist destination (in this case is the national park) can be evaluated based on a number of categories. These categories can be implemented with the tourist behavior so that the level of halal in the national park could be assessed. Critical evaluation of the categories is expected to provide an overview of challenges and recommendations for tourism in national parks as a halal product.

\section{The Elements of Halal Tourism in National Park}

Halal means "something permitted, by looking at the absence of restrictions, and doing what God allows" [22 $]^{(\mathrm{p} 2)}$. In other words, halal means something that is allowed in the categorization of behavior according to Islamic law. In addition to halal, there are other degrees of behavior such as fard (mandatory), mustahab (recommended), makruh (not recommended), and haram (forbidden) $[22]^{(\mathrm{p} 2)}$. In relation to other degrees of behavior, then halal tourism can be defined as tourism that is implemented without doing behaviors below the degree of halal such as makruh or haram according to Islamic law. Or in other words, halal tourism is a tourism activity that aligns and has behavior in accordance with Islamic law [1].
Although halal is likely known in the context of food, however, the element in order to fulfil the degree of halal in tourism activity can be implemented widely. For example, the degree of halal can be seen from the perspective of accommodation, tourism activities (consider pray time in travel time), food and travelling facilities [22]. Furthermore, the halal degree also can be asses in more details, for example, Samori et al [1]. in their study suggests there are three levels of halal in the accommodation perspective, start from basic, medium and extensive level. The basic level offers halal food, does not offer alcoholic beverages, provides the mecca signs in the room, provides the praying kit, and has a squat toilet. The intermediate level offers all basic level plus different recreational facilities across gender, prayer room, does not provide adult entertainment, the announcement of prayer time, and next to or at least, giving mosque direction. The extensive level offers all basic and intermediate level and, in addition, they provide zakat counters, brochures related to Islam, Islamic teaching classes, Azan prayers downstairs and Islamic tour packages.

Therefore, several elements should be evaluated to form the character of halal tourism in the National Park which is not only related to accommodation. Tourism-related aspects such as regular tourists' activities, tourist information centers, exhibitions, trade events and outdoor activities (e.g. camping, hiking, etc.) should be asses to have the value of halal. From those elements, the concept of aurat (body parts required by Islam to be covered) is one of the practical elements in the implementation of Islamic norms so that the use of hijab can be a signal in order to distinguish public tourism and halal tourism [23]. Accordingly, the segregation of men and women for non-family must also be implemented in every outdoor activity, or as an alternative, it can be cluster by grouping in family-friendly or family.

The involvement of culture is an element of tourism that is rarely discussed in the halal tourism literature, especially with regard to tourism in national parks [24]. However, Islam itself has been supporting in cultural diversity where one verse in the Koran states that God makes people in nations and tribes so that they know each other, and the most honorable among the people in the sight of God is the devout people (Al Hujuraat, 13). This verse assures that cultural diversity is a natural and non-discriminatory [24].

The existence of this teaching shows that culture is also an important aspect of halal tourism. Nevertheless, some national parks have problems in preserving the culture especially during the process of its formation. For example, there are some histories that indigenous people were being forcibly relocated and prohibited from entering and extracting natural resources in protected areas so that the site loses local cultural elements [17]. The avoidance of national parks on the local culture aspect is contradicted with discretion given to visitors to enjoy the parks. In fact, that treatment to indigenous people also does not give tourists a chance to know the local cultures and tribes.

However, if there is an interaction between tourists and local people in the national park or at least in its periphery, other problems may arise because such interactions may place 
tourists in non-halal situations. This happens when tourists are dealing with locals who show 'haram' behavior such as not wearing clothing that covers their body. This possibly happens especially in national parks in tropical areas where local people use minimal clothing as a form of adaptation with the hot and humid weather. Herein lies the consideration, whether the Muslim tourists should make contact with local culture but contradict the concept of halal, or avoid local culture even though it is also an important aspect of halal tourism. Finally, a reconciliation between park managers and local communities should be sought so that local people can keep their original life, but on the other hand, Muslim tourists can interact while maintaining respect in the intercultural mix of different cultures. Something that is easier to say than done.

Interaction or 'knows each other' in Islam has the meaning that both parties have an active role in communication [25]. One example of an imbalance of an active role in tourism activities is shown by the study of Mowforth and Munt [17] in Mulu National Park, Sarawak, where one of the foreign tourists expressed:

"I realized how the Penan are being treated like animals in a zoo. Almost every tourist group that visit the park is taken there to walk around and look at the Penan "way of life". A longhouse is now in the process of being built for them, which as you know is not the way the Penan live. The atmosphere is one of despair". [17] ${ }^{(\mathrm{p} 265)}$

Tourism activities in the case above is not a concept of interacting in Islamic tourism because there is no conversation and social interaction. As said by the tourist above, the indigenous people of Penan just as objects so like animals in the zoo. The concept of knowing each other must be interpersonal interactional in the atmosphere of friendship and mutual respect for each other [25]. In this way, the cultural aspects of the national park can be shaped accordingly with halal tourism.

Another element of halal tourism that also deserve attention is sharia-based finance transactions [26]. For Muslims, they would prefer a tourism provider that has shariah-based finance facilities because it uses a financial transaction system in the form of profit sharing, rather than the interest that is considered haram [27]. Although several sharia banks are part of conventional banking and get funds based on interest, the use of sharia banking more gives a positive impression for Muslim tourists [26].

Another element of halal tourism that is quite important and in line with the activities within the national park is in the context of conserve nature and cleanliness. Islam rejects the destruction of nature that is God created so any actions that destroy nature are interpreted as bad behaviors. This is documented in the QS Ar Rum verse 41 which states "it appears that the damage on land and at sea is due to the deeds of human hands," and QS Al-A'raf verse 56 "and do not corrupt the earth after it was created beautifully. Similarly, in the context of maintaining cleanliness which in Islamic teachings states "Cleanliness is part of faith" (hadith riwayah Ahmad, Muslim and Tirmidhi).
The above discussion thus reveals at least several characteristics of halal tourism that can be proposed as an instrument to evaluate national parks to become part of halal tourism. These instruments are:

a. The history of the formation of a National Park that should consider to the right to life, or in other words no conflict occurred at the time of the establishment of the National Park.

b. Sharia lodging compliance, not least including gender segregation and worship facilities.

c. Tourism activities, including in this aspect such as cultural social interaction, hygienic and conserve the nature.

d. Halal food and beverages, both provided at the inn and available nearby.

e. Recognition of the Islamic dress and behavior of all parties involved.

f. Sharia-based transaction system or zakat counter provision.

In addition, for special occasions such as the month of Ramadhan, halal tourism should consider certain specialties such as providing meals before and after fasting time, do not encourage Muslim tourists in any activities that could break the fast, and when possible, the organization of Tarawih prayer activities.

\section{RESEARCH METHOD}

The descriptive method is used because this current research is categorized in the social science which according to Rhama's study [4] is more appropriate if using the qualitative approach. Moreover, this method can deliver the detailed description of the situation and conditions that exist in the field [28]. Accordingly, the focus of this study refers to the elements mentioned above and implemented in Sebangau National Park and Tanjung Putting National Park in Central Kalimantan, Indonesia as its research location. The primary data with the qualitative method is collected by (i) interview and (ii) observation and it is also supported by secondary data such as (iii) journals, books, magazines and website.

The data that has been obtained is then analysed using the interactive data analysis technique in accordance with the previous study by Miles, Huberman and Saldaña [29] which has three phases namely (a) the data reduction phase to filter the data and focus on something important that can be used show some patterns (b) The data display phase is used to present the data systematically so the result is easy to understand and, (c) the phase to draw conclusions and verification. The findings and discussion of this research analysis are discussed further in the following section. 


\section{RESULT AND DISCUSSION}

\section{A. History}

National Parks that is selected to implement the concept of halal tourism should be free from conflicts started from its history of the formation to its management.

\section{B. Accommodation}

Visitors accommodation for halal tourists in national parks is relatively easy for Muslim countries, while may be more difficult for non-Muslim areas. The study of tourist segmentation in the United States shows the majority of ecotourism object visitors (e.g. national park) are coupled $(58 \%-61 \%)$, meanwhile families are only $15-26 \%$ [30]. Thus, gender segregation should become a priority compare with a family-friendly cluster. This is included in confirming that the couple who visit is married therefore allow them to be placed in the same room. However, another study from Wight [30] also shows that the profile of Australian tourists visiting nature tourism objects is dominated by independent individuals $(45 \%$ $-66 \%$ ) compared to family or coupled travellers. In situations like this, gender segregation takes place by itself.

Another challenge faces by Muslim tourists for the national park is its location relatively far with Mosque or places of prayer. However, Muslims can actually pray in any place as long as the place is considered clean [31] [32]. Nevertheless, the provision of special facilities for worship services reflects a high regard for Muslim visitors. The accommodation providers closest to the national park location are required to be able to provide special worship rooms, at least musholla for collective worship, and Qibla sign in the rooms for private worship. If possible, the provision of accommodation can work with local communities by taking advantage of nearby places of worship, such as community mosques, so that tourists can also interact with the community in the mosque which is a universal place of worship for Muslims, regardless of their origin.

\section{Activity}

The opportunity to implement the halal tourism activities in the national park can be done by providing halal tours, complete with a tour guide that understands the Islam teaching. In addition, Muslim tourists will have a valuable experience in admiring God's creation by travelling in a natural environment. Generally, tourists see the jungle as a spiritual, romantic, rich, luxurious, dynamic, relieving and mysterious attraction [33]. Therefore, the national park is also a source to build the foundation of spiritual opportunity, as well as scientific, educational and recreational purposes [34]. This makes the emergence of spiritual connections between people and places, as do physical connections with humans [35]. Tourist guides, as well as Islam teacher, can provide interpretations that guide visitors to appreciate the God's greatness and how small human positions in nature in various occasions, especially in mystical and contemplation situations such as doing camping activities in national parks.

\section{Food/drink}

Being in a wild area, there is a tendency to use local resources to provide culinary delights for tourists. Fish-based meals can be given to the national parks visitors in the tropical country because the protection of fish species is not as restrictive as other wild animals that live on land. In addition, Muslims are also permitted to consume fish. It would also be better if there is a halal certificate from a special authority to convince Muslim tourists for their food and drink.

\section{E. Dress code}

Another element that needs to be considered further is the dress code to conduct tourism activities. Muslim tourists should use proper clothes that cover their aurat when doing outdoor activities such as swimming.

\section{F. Finance}

The use of Syariah-based financial instruments is seen to be outside the scope of national park management. However, park managers may be affiliated with sharia banks and provide basic facilities such as sharia bank's ATMs at the tourist information centre. Sharia banking services can facilitate visitors to make cash withdrawals and create a more visible impression of sharia.

\section{CONCLUSION}

For several reasons, nature tourism in the national park itself has complied with the rules of halal tourism, mainly in the perspective of the obligation to maintain cleanliness and avoid nature destruction. In particular, regarding the location of national parks in Indonesia, that majority population is Muslim, the accommodation providers are generally easy to fulfil the criteria of halal lodgings. Accommodation can be designed by adapting local elements and underpinning local aspects without ignoring Islamic values. However, there are still things that need to be improved, such as:

1. Provide religious facilities that can dwell with the local people.

2. Confirming the marital status of visitors who visit in pairs.

3. The interpersonal interaction between tourists and local people in an atmosphere of mutual respect.

4. The halal tour package of the national park complete with the tour guide who understand the Islam rules.

5. Not providing wild-based foods specifically forbidden or haram.

6. Ensure appropriate dress codes in serving tourists as well as implementing risky activities such as swimming and cycling.

7. Providing sharia-based financing facilities and zakat/donation outlets.

The attention to the above elements and criteria that have been discussed above can encourage nature tourism to be part 
of halal tourism. Nevertheless, tourists' consumptive behaviour still needs to be aware as the halal tourism implemented in national parks can present a new problem for the nature capacity in the park itself.

And it is also important to remember if recreational activities are fundamental to tourism activities that do not recognise borders. ${ }^{36-38}$ Various social and environmental approaches can be a tourism motivation such as ecotourism, marine tourism, pilgrim and many others tourism types [5] [39]. Halal tourism is just one of the new phenomena that are a niche market in the tourism industry that emphasises the religious approach. It is possible that the halal tourism in the national park in the future is only one part of mass tourism that encourages a high number of visits and leads to lower the integrity of nature owned by the national park.

\section{ACKNOWLEDGMENT}

This research is supported by PT. Barama Intercity Travel Consultant. The authors are grateful for some reviews that have been given at the phase of research submission so it's useful for the development of this research. This research is expected to develop a new way of thinking for the implementation of halal tourism in distinctive tourist destinations in Indonesia.

\section{REFERENCES}

[1] Z.Samori; N.Z.M.Salleh and M.M.Khalid, Current trends on Halal tourism: Cases on selected Asian countries. Tourism Management Perspectives. 2016.

[2] R. Bocock. Consumption. London: Routledge. 1993.

[3] D.Crouch. Tourism, consumption and rurality. In P. Cloke, T. Marsden and P. Mooney (Ed.), Handbook of rural studies (pp. 355-363). London: Sage Publications. 2006.

[4] B. Rhama, The implications of the values and behaviours of actors for ecotourism policy: A case study of Sebangau National Park, Central Kalimantan, Indonesia. Unpublished doctoral dissertation. University of Central Lancashire, Preston, United Kingdom. 2017.

[5] R. Sharpley, R. Tourism, religion and spirituality. The Sage handbook of tourism studies. 2009. pp.237-253

[6] A.G.Woodside and C.A. Dubelaar. "General theory of tourism consumption systems: A conceptual framework and an empirical exploration". Journal of Travel Research. 2002. 41(2). pp.120-132

[7] S.H.Schwartz. "Are there universal aspects in the structure and contents of human values?" Journal of Social Issues. 1994. 50(4). pp.19-45

[8] S.H. Schwartz; G. Melech; A.Lehmann; S. Burgess; M. Harris and V. Owens, "Extending the cross-cultural validity of the theory of basic human values with a different method of measurement". Journal of Cross-Cultural Psychology. 2001. 32(5). pp. 519-542

[9] G. Wal and A. Mathieson. Tourism: change, impacts, and opportunities. Pearson Education. 2006

[10] A. Weidenfeld; R. Butler and A.M. Williams. Visitor attractions and events: locations and linkages. Routledge. 2016.

[11] A. Mohsin; N. Ramli and B.A. Alkhulayfi. Halal tourism: Emerging opportunities. Tourism Management Perspectives. 2016. 19. pp. 137-143

[12] International Travel Week [Internet]. Abu Dhabi: International Travel Week; 2016. The World Halal Tourism Awards 2016. [updated 2017; $\begin{array}{lllll}\text { cited } 2017 \text { Jan 4]. Available from: } & \end{array}$ http://itwabudhabi.com/awardswinner.html
[13] P. Brouder and C. Fullerton. Co-evolution and sustainable tourism development. Tourism Destination Evolution. 2017. pp. 149-164

[14] D. A. Carson and D.B. Carson. Path dependence in remote area tourism development: Why institutional legacies matter. Tourism destination evolution. 2017.pp. 103-122

[15] J. Meekes; C. Parra and G. de Roo. Regional Development and leisure in Fryslân: A complex adaptive systems perspective through evolutionary economic geography. Tourism destination evolution. 2017. pp.165-182

[16] H. Halkier and L. James. Destination dynamics, path dependency and resilience. Tourism destination evolution. 2017. pp.19-42

[17] M. Mowforth and I. Munt. Tourism and Sustainability: Development, globalisation and new tourism in the third world. 4th Edition. Routledge. 2016.

[18] J. Angell. The wilderness solo: An empowering growth experience for women. Women \& Therapy. 1994. 15(3-4), pp. 85-99

[19] M.C. Caulkins; D.D.White and K.C. Russell. The role of physical exercise in wilderness therapy for troubled adolescent women. Journal of Experiential Education. 2006. 29(1). pp.18-37

[20] P.F.J. Eagles,. International trends in park tourism: The emerging role of finance. The George Wright Forum. 2003. 20(1). pp.25-57

[21] T.E. Hall; D.N.Cole and D. Cole. Immediate conscious experience in wilderness: A phenomenological investigation. In D. N. Cole (Ed.), Proceedings of the conference of wilderness visitor experiences: Progress in research and management (37-49). Missoula: U.S. Department of Agriculture, Forest Service, Rocky Mountain Research Station. 2011.

[22] M. Battour and M.N. Ismail. Halal tourism: Concepts, practises, challenges and future. Tourism Management Perspectives. 2015.

[23] M. Battour; M.N.Ismail; M. Battor and M.Awais. Islamic tourism: an empirical examination of travel motivation and satisfaction in Malaysia. Current Issues in Tourism. 2017. 20(1). pp. 50-67

[24] D. Timothy and T. Iverson. Tourism and Islam: Consideration of culture and duty. In D. Timothy, \& D. Olsen (Eds.), Tourism, religion and spiritual journeys (pp. 186-205). Oxford, UK: Routledge. 2006.

[25] G. Rong. Identity, Interaction and Islamic Practice: Hui Muslims in China. Leuven, Belgium: Leuven University Press. 2016.

[26] N.K. Gabdrakhmanov; N.M.Biktimirov; M.V. Rozhko and L.V. Khafizova. Problems of Development of Halal Tourism in Russia. Journal of Organizational Culture, Communication and Conflict. 2016. 20. pp. 88

[27] G. Rexhepi and N. Ramadani. Ethics and Social Responsibility in Islamic Finance. In Ramadani, V., Dana, L., Gërguri-Rashiti, S., Ratten, V. (Eds), Entrepreneurship and Management in an Islamic Context (pp. 133-142). Switzerland: Springer International Publishing. 2017.

[28] H.B Sutopo, H. B. Qualitative Research Methodology: Theoretical and applied basis in research (Metodologi Penelitian Kualitatif: Dasar teori dan terapannya dalam penelitian). Surakarta: Sebelas Maret University. 2002.

[29] M.B. Miles; A.M.Huberman and J. Saldana. Qualitative data analysis. Sage. 2013.

[30] P.A. Wight. Ecotourists: Not a homogeneous market segment. The encyclopedia of ecotourism. 2001, pp. 37-62

[31] S.A. Ali. Perception of Muslims publicly praying on campus. AAS 258; Spring 2016.

[32] M.H.Pedersen. Becoming Muslim in a Danish Provincial Town. In Strhan, A., Parker, S. G. \& Ridgely, S (Eds), The Bloomsbury Reader in Religion and Childhood, (131-138 p). London: Bloomsbury Publishing. 2017.

[33] W. Frost. Rainforests. The encyclopedia of ecotourism. 2001.193-204 p. 
[34] L.J.Lawton Public protected areas. The encyclopaedia of ecotourism. 2001. 287-302 p.

[35] B. Weiler and S.H. Ham, Tour guides and interpretation. The encyclopedia of ecotourism. 2001. 549-563 p.

[36] T. Coles and M.Hall. Editorial: The Geography of Tourism is Dead. Long Live Geographies of Tourism and Mobility, Current Issues in Tourism. 2006. 9:4-5, pp. 289-292
[37] B.A. McKercher. chaos approach to tourism. Tourism Management. 1999. 20(4), pp. 425-434

[38] T.H. Sofield, Border tourism and border communities: An overview. Tourism Geographies. 2006. 8(2), pp. 102-121

[39] D.Timothy and D.Olsen (Eds.). Tourism, religion and spiritual journeys (Vol. 4). Routledge. 2006. 